Japan. J. Med. Sci. Biol., 35, 239-242, 1982

Short Communication

\title{
EXPERIMENTAL TOXICOINFECTION IN INFANT MICE CHALLENGED WITH SPORES OF CLOSTRIDIUM BOTULINUM TYPE E
}

\author{
Hiroshi MitAmURA, Kunio KAMEYAMA and Yoshiaki ANDO \\ Hokkaido Institute of Public Health, North 19, West 12, Kita-ku, \\ Sapporo 060, Japan
}

(Received May 6, 1982. Accepted June 25, 1982)

\begin{abstract}
SUMMARY: Conventionally raised suckling mice were given $10^{7}$ spores of a strain of Clostridium botulinum type $\mathbf{E}$. Most but not all infant mice aged 8 through 19 days at the time of administration died after developing symptoms typical of botulism. However, none of the infant mice challenged with the spores at dose levels lower than $10^{6}$ spores/mouse developed illness.
\end{abstract}

Since 1976 up to date, infant botulism has been reported from various countries including USA (181 cases), Australia (5 cases), Canada ( 1 case), and England (1 case), showing apparently world-wide occurrence of the disease (Arnon, Damus and James, 1981). All these cases have been caused by either type A or type B toxin except two cases from New Mexico caused by type $\mathrm{F}$ and $\mathrm{B}$ toxins. No case of type $\mathrm{E}$ infant botulism has hitherto been reported.

Several animal experiments have been made by several investigators to study some aspects of botulism in human infants. Miyazaki and Sakaguchi (1978), in their studies on the experimental botulism in chickens, demonstrated that the site of production and absorption of botulinum toxin is the cecum. Sugiyama and Mills (1978), using infant mice as a model for infant botulism, reported that botulinum toxin was identified in the intestines of the mice challenged with $10^{5}$ spores of $C$. botulinum type A only when the animals were 7 to 13 days old. In a subsequent study with germ-free mice, Moberg and Sugiyama (1979) suggested that the microbial interaction between some organisms in the intestinal microflora and C. botulinum is important in the pathogenesis of infant botulism. The age-limited susceptibility of conventional infant rats was similar to that of infant mice (Moberg and Sugiyama, 1980).

Since the majority of outbreaks of botulism in Japan have been caused by type $\mathbf{E}$ organism and its widespread distribution in soil has been reported (Ando, 1981), the present investigation was undertaken to determine whether toxicoin-

三田村 弘・亀山邦夫・安藤芳明（北海道立衛生研究所 札幌市北区北 19 条西 12 丁目） 
fection comparable to infant botulism can occur in suckling mice upon administration of type $\mathrm{E}$ spores.

Spores of $C$. botulinum type E, strain Iwanai, were prepared by the method described by Schmidt and Nank (1962). To eliminate vegetative cells and debris, the spores were treated with an enzyme mixture consisting of trypsin $(50 \mu \mathrm{g} / \mathrm{ml})$ and lysozyme $(100 \mu \mathrm{g} / \mathrm{ml})$ in $0.05 \mathrm{M}$ phosphate buffer $(\mathrm{pH} 8.1)$ at $37 \mathrm{C}$ for $60 \mathrm{~min}$ before washing several times with distilled water. Clean spores were suspended in distilled water $\left(2.1 \times 10^{9}\right.$ spores $\left./ \mathrm{ml}\right)$ and kept frozen until used.

Each litter of infant mice (HA/ICR strain) was kept in its own cage to prevent cross-infection. All infant mice of a litter were administered with the same dose of spores on the same day. Usually, suckling mice younger than 7 days and older than 8 days of age were inoculated by intragastrical (ig) injection and by oral administration, respectively. A hypodermic needle (26 gauge) was used to inject spores through the abdominal wall into the stomach. For oral administration, a plastic catheter (24 gauge) was used. Spore suspensions were thawed, heated at $65 \mathrm{C}$ for $10 \mathrm{~min}$ to exclude effects from extraneous toxin, and administered in $0.10-\mathrm{ml}$ volumes.

Preliminary experiments revealed that some but not all 10-day-old infant mice administered perorally with $10^{7}$ spores developed illness within two or three days and died in additional three or four days after developing symptoms typical for botulism, whereas none of the adult mice receiving the same dose of spores died. Thereafter, an experiment was made on the relationship between age of mice at the time of challenge with $10^{7}$ spores and their fatality (Table I). The results were slightly variable in the two experiments, but showed evidently common tendencies. Suckling mice younger than 7 days of age at the time of ig injection did not show any sign of botulism, nor died over the period of raising. However, most but not all infant mice aged 8 through 19 days at the time of oral administration became ill within two or three days and died in additional three or four days after progressive illness and respiratory difficulties characteristic of botulism. Mice older than 20 days of age and adult mice were completely resistant to the challenge, as was the case with suckling mice less than 7 days of age. All extracts of the large intestines from the dead infant mice were toxic when assayed in adult mice by ip injection, though quantitative toxin tests were not performed. Microscopic observations indicated that spores of $C$. botulinum had already germinated and outgrown in the intestinal tracts. However, neither spore germination nor toxin production could be detected in the intestinal tracts of mice that remained well, when the animals were sacrificed and tested for toxin in 10 days post-challenge. The number of spores necessary for causing botulism was determined with litters of 10-day-old mice by challenging with different spore doses. Most of mice administered perorally with $10^{7}$ or $10^{8}$ spores died of botulism in 4 to 6 days after administration, but all mice survived the challenges with $10^{4}, 10^{5}$, and $10^{6}$ spores (Table II). In these experiments, separate groups of 10 adult mice were each challenged with $10^{8}$ spores by the ip or ig route; none developed signs of botulism. 
TABLE I

Influence of age of mice on susceptibility to toxicoinfection with C. botulinum type E spores*

\begin{tabular}{cccc}
\hline \multirow{2}{*}{ Age $($ days $)$} & \multicolumn{2}{c}{ Mice died $/$ tested } & \multirow{2}{*}{ Days to onset of botulism } \\
\cline { 2 - 3 } & Expt 1 & Expt 2 & \\
\hline 5 & $0 / 10$ & $0 / 10$ & \\
6 & $0 / 10$ & $0 / 10$ & \\
7 & $0 / 10$ & $0 / 10$ & \\
8 & $6 / 10$ & $8 / 13$ & $5-6$ \\
9 & $8 / 11$ & NT** & 5 \\
10 & $\mathrm{NT}$ & $\mathrm{NT}$ & \\
11 & $8 / 11$ & $\mathrm{NT}$ & $4-5$ \\
12 & $7 / 10$ & $6 / 9$ & 4 \\
13 & $5 / 10$ & $5 / 9$ & $4-6$ \\
14 & $4 / 9$ & $3 / 8$ & 4 \\
15 & $5 / 10$ & $3 / 8$ & 4 \\
16 & $4 / 10$ & $\mathrm{NT}$ & $5-8$ \\
17 & $\mathrm{NT}$ & $\mathrm{NT}$ & \\
18 & $10 / 10$ & $8 / 10$ & $4-7$ \\
19 & $7 / 10$ & $10 / 12$ & $4-6$ \\
20 & $0 / 8$ & $0 / 9$ & \\
21 & $0 / 10$ & $0 / 9$ & \\
22 & $0 / 13$ & $\mathrm{NT}$ & \\
23 & $0 / 12$ & $0 / 8$ & \\
\hline
\end{tabular}

* $10^{7}$ spores per mouse were administered.

** NT: not tested.

\section{TABLE II}

Fatalities of infant mice* administered with different doses of C. botulinum type E spores

\begin{tabular}{ccc}
\hline Spores/mouse & Mice died/tested & Days to onset of botulism \\
\hline $10^{8}$ & $10 / 12$ & $4-5$ \\
$10^{7}$ & $12 / 14$ & $4-6$ \\
$10^{6}$ & $0 / 12$ & \\
$10^{5}$ & $0 / 14$ & \\
$10^{4}$ & $0 / 12$ & \\
\hline
\end{tabular}

* 10-day-old mice were used.

Since no intrasporal toxin was detected in the numbers of type $\mathbf{E}$ spores being administered, this is an experimental botulism caused by toxicoinfection with $C$. botulinum type $\mathrm{E}$ spores. The previous findings that the germination of $C$. botulinum type $\mathrm{E}$ spores showed the minimum requirement of a mixture of L-alanine, lactate, and bicarbonate (Ando and Iida, 1979) suggest that certain 
lactate-producing bacteria predominant in the microflora of intestinal tracts of suckling mice would stimulate germination of type $\mathrm{E}$ spores so that the organism can grow and produce toxin in some sites of the intestines.

\section{REFERENCES}

Ando, Y. AND IIDA, H. (1970): Factors affecting the germination of spores of Clostridium botulinum type E. Japan. J. Microbiol., 14, 361-370.

Ando, Y. (1981): Recent problems in botulism and its control. J. Food Hyg. Soc. Japan, 22, 455-461 (text in Japanese).

Arnon, S. S., Damus, K. And James, C. (1981): Infant botulism: Epidemiology and relation to sudden infant death syndrome. Epidemiol. Rev., 3, 45-66.

MryazAKI, S. AND SAKAguchi, G. (1978): Experimental botulism in chickens: The cecum as the site of production and absorption of botulinum toxin. Japan J. Med. Sci. Biol., 31, 1-15.

Moberg, L. J. ANd Sugiyama, H. (1979): Microbial ecological basis of infant botulism as studied with germfree mice. Infect. Immun., 25, 653-657.

Moberg, L. J. AND SugIyama, H. (1980): The rat as an animal model for infant botulism. Infect. Immun., 29, 819-821.

Schmidt, C. R. AND NANk, W. K. (1962): Radiation steriliation of food. II. Some aspects of the growth, sporulation, and radiation resistance of spores of Clostridium botulinum, type E. J. Food. Sci., 27, 77-84.

Sugiyama, H. AND Mills, D. (1978): Intraintestinal toxin in infant mice challenged intragastrically with Clostridium botulinum spores. Infect. Immun., 21, 59-63. 